\title{
Kesiapan Mengadopsi Sistim Informasi Pada Rumah Sakit Pemerintah di Kota Padang
}

\author{
Vera Pujani ${ }^{a}$, Rima Semiarty ${ }^{b}$, Dede Tri Wahyu Kotama ${ }^{a}$ \\ ${ }^{a}$ Prodi Manajemen, Fakultas Ekonomi, Universitas Andalas, Padang, 25162, Indonesia \\ ${ }^{b}$ Prodi Ilmu Kedokteran, Fakultas Kedokateran, Universitas Andalas, Padang, 25162, Indonesia
}

\section{INFORMASI ARTIKEL}

Sejarah Artikel:

Diterima Redaksi: 05 Juli 2018

Revisi Akhir: 30 Januari 2019

Diterbitkan Online: 30 April 2019

\section{KATA KUNCI}

Readiness,

Adopsi,

Sistim Informasi Manajemen Rumah Sakit,

Rumah Sakit Pemerintah Padang

KORESPONDENSI

Telepon: +6281374713060

E-mail: verapujani@eb.unand.ac.id

\section{A $\quad$ B $\quad \mathbf{S}$ T $\mathbf{R}$ A A C $\mathbf{C}$}

Studi ini bertujuan untuk mengevaluasi pengaruh faktor kesiapan rumah sakit daerah milik pemerintah di kota Padang dalam mengadopsi E-health atau Sistim Informasi Manajemen rumah sakit. Faktor kesiapan yang akan diukur adalah adanya kesiapan pokok (core), kesiapan structural teknologi (structural), kesiapan social (societal), kesiapan untuk menggunakan (engagement), upaya yang dilakukan (effort), dan capaian kinerja (performance) terhadap adopsi $e$-health. Penelitian ini menggunakan metode kuantitatif dan survey terhadap 80 orang pengguna sistim informasi pada tiga rumah sakit pemerintah di Kota Padang. Pemilihan sampel berdasarkan metode purposive sampling, karena hanya ditujukan bagi yang pernah mengoperasikan sistim informasi di rumah sakit. Data yang diperoleh dari kusioner akan diolah menggunakan analisis regresi berganada dengan aplikasi stata. Studi ini menguji 6 hipotesis dan menghasilkan bahwa semua faktor kesiapan mempengaruhi adopsi $e$-health di rumah sakit milik negara di Kota Padang. Dari semua variable diteliti, ditemukan rata-rata tertinggi pada variabel capaian kinerja, artinya rumah sakit yang bisa mengadopsi $e$-health, mesti memiliki kinerja yang baik juga. Implikasi dan saran dijelaskan pada bagian akhir dari penelitian ini. Untuk studi lanjut mesti dipertimbangkan factor lain seperti komitmen pimpinan, dan ketersediaan dana dalam mengadopsi $e$-health di rumah sakit pemerintah di Indonesia.

\section{PENDAHULUAN}

Penggunaan teknologi informasi dalam aspek kesehatan sudah menjadi kebutuhan begitu penting terkait juga dengan pemahaman, kemampuan dan sumberdaya untuk meningkatkan kualitas pelayanan kesehatan [1]. Teknologi internet dan teknologi kesehatan lainnya menyediakan media baru untuk menghubungkan antara sistim informasi kesehatan, pelayanan kesehatan masyarakat dan dunia usaha untuk saling bekerjasama [2]. Teknologi informasi kesehatan (e-health) merupakan Teknologi Informasi dan Komunikasi (TIK) yang mendukung kegiatan dibidang kesehatan mencakup ; pelayanan, perawatan, literasi, dan penelitian pendidikan dan pengetahuan kesehatan.

E-health dapat digunakan untuk kegiatan yang terintegrasi antara pekerjaan adiministrasi dalam memberikan pelayanan kesehatan kepada masyarakat, informasi dari kegiatan professional/dokter dan pemamnfaatan konsep e-commerce dan e-business [3]. Pemanfataan teknologi informasi ini tidak hanya digunakan oleh negara maju saja, namun juga diterapkan oleh negara-negara sedang berkembang, karena di era globalisasi saat sekarang ini para pemimpin organisasi lebih cenderung mengambil keputusan pada perubahan solusi yang akan digantikan dengan sistem informasi yang didukung dengan Teknologi Informasi (TI) yang tepat guna [4].

Pemanfaatan teknologi informasi saat sekarang ini tidak terlepas dari penggunaan internet. Internet yang merupakan jaringan yang memiliki jangkauan terluas kepada semua orang dengan memberikan informasi sehingga memperluas peluang bisnis di seluruh dunia [5]. Pengguna internet di Indonesia adalah 53\% dari total penduduk Indonesia yaitu 143,260,000 dan sebagai 5 negara tertinggi pengguna internet dunia [5].

Keadaan ini juga di dukung oleh adanya kebijakan dari Menteri Kesehatan Indonesia tentang penggunaan teknologi informasi 
untuk bidang kesehatan (e-health) telah diatur dalam UndangUndang No 36 Tahun 2009 tentang penyelenggaraan pelayanan kesehatan yang efektif dan efisien melalui sistem informasi yang terkait dengan berbagai sektor yang lain. Disamping itu, terdapat Keputusan Menteri Kesehatan (KepMenkes) nomor 192/MENKES/SK/VI/2012 tentang pemanfaatan Teknologi Informasi Komunikasi (TIK), dan pengembangan $e$-health dalam KepMenkes RI No.374/MENKES/SK/V/2009 tentang Sistem Kesehatan Nasional (SKN). Sehingga perkembangan teknologi informasi di sektor kesehatan saat sekarang sudah mulai digunakan untuk memberikan pelayanan keseluruh masyarakat yang mendorong terciptanya sistim informasi kesehatan elektronik (e-health).

Banyaknya jumlah pengguna internet di Indonesia dan adanya kebijakan pemerintah dalam menggunakan sistim informasi di sektor kesehatan, masih belum mampu mengoptimalkan penggunaan sistim informasi kesehatan di Indonesia terutama di rumah sakit. Pemerintah Indonesia sangat mendukung penggunaan sistim informasi di sektor kesehatan, namun masih banyak insdustri dan rumah sakit di Indonesia yang belum menjalankan sistem informasi kesehatan ini (e-health) secara optimal, dikarenakan masih banyaknya kekurangan dari berbagai hal, mulai dari jaringan komunikasi yang buruk, kekurangan kemampuan/pengetahuan karyawan, budaya organisasi dan aspek lainnya [4].

Beberapa studi telah dilakukan tentang penggunaan sistim informasi di beberapa rumah sakit di Indonesia seperti di rumah sakit, RSCM, RSAD, Dharmais, Medistra, Adi Husada dan lainnya [6]. Penggunaan Sistim Informasi Kesehatan (SIK) di Indonesia sudah mulai diterapkan oleh pemerintah Kota Surabaya, dimana sistem SIK ini merupakan salah satu program unggulan berbasis online yang termasuk Top 25 pelayanan publik terbaik tingkat nasional pada tahun 2015 [7] yang didapatkan oleh pemerintah Surabaya dan menjadikan kota smart city. Dengan adanya SIK di Kota Surabaya tidak hanya menjadi solusi pelayanan, namun juga memudahkan masyarakat untuk mendapatkan pelayanan yang lebih baik dan efektif. Selain itu sistem SIK juga menjadi pedoman bagi kelurahan dan kabupaten lainnya di Kota Surabaya yang ingin menerapkan sistem ini.

Sementara itu, studi tentang penggunaan SIK di Sumatera Barat dan khususnya kota Padang masih belum banyak diteliti, walaupun beberapa rumah sakit sudah menetapkan pelayan kesehatan yang optimal sebagai target capaian di beberapa rumah sakit baik rumah sakit pemerintah maupun swasta di Kota Padang. Kota Padang memilik rumah sakit yang sudah tergolong lengkap menggunakan beberapa teknologi kesehatan yang modern, namun belum banyak yang meneliti peranan penggunaan teknologi kesehatan dalam meningkatkan pelayanan kepada masyarakat terutama di Rumah Sakit milik pemerintah.

Sistem Informasi Kesehatan/SIK (e-health) telah berkembang dengan pesat untuk memberikan layanan kesehatan kepada masyarakat di antaranya yang banyak di gunakan adalah electronic health record, telemedicine, consumer health informatics, health knowledge management, virtual healthcare team, mobile-health, Healthcare Information Systems [7].

Kegiatan berbasis elektronik (e-busines) merupakan inovasi paling penting sejak munculnya pertumbuhan teknologi internet

10 Vera Pujani saat ini [8]. Salah satu penentu dicapainya keunggulan bersaing dari perusahaan-perusahaan di semua jenis industri adalah kemampuan untuk menggunakan teknologi informasi dan komunikasi [9]. Karakteristik khusus dari internet seperti kecepatan, penggunaan yang mudah, berbiaya rendah dan jangkauan akses yang luas membuat electronic business atau disebut juga $e$-business telah meningkat secara global, membawa negara-negara bersama dalam satu jaringan ekonomi global [10]. Penggunaan yang luas dari internet menjadi hal yang paling penting yang merubah model atau cara menjalankan aktifitas orgainsasi dan perusahaan terutama dalam mencapai produktifitas kerja menuju lebih baik lagi. Untuk alasan ini, internet telah dikenal sebagai sebuah peluang baru dari semua sektor diseluruh dunia untuk mencapai tujuan-tujuan dari aktifitas mereka, dalam hal peningkatan efisiensi dan kualitas [11].

Pertumbuhan yang pesat dari teknologi informasi selama setengah abad yang lalu tidak diikuti oleh kesuksesan dalam pelaksanaannya [12,13]. Penggunaan dari teknologi baru, khususnya teknologi informasi atau sistem informasi, oleh berbagai tipe organisasi mengalami kegagalan dibandingkan keberhasilan [14] karena mahalnya investasi pada IT, kinerja yang rendah [15], dan nilai yang rendah dan juga kontribusi yang rendah pada produktivitas, kualitas dan persaingan [16].

Ketidakberhasilan dari penerapan teknologi informasi / sistem informasi mungkin disebabkan oleh : (1) adanya kesenjangan antara teori-teori secara akademik, kerangka konseptual dan praktek didunia nyata pada organisasi-organisasi [12]; (2) Tidak cocoknya dari banyaknya tujuan-tujuan perencanaan strategi dari sistem-sistem informasi dalam sebuah lingkungan yang dinamis [17]; dan (3) Pembentukan yang rendah dari metode-metode evaluasi dari sistem-sistem informasi [16].

Oleh karena itu, klasifikasi dari sukses dan gagalnya penerapan sistem-sistem informasi menyebabkan kesulitan-kesulitan, karena menimbulkan perbedaan perspektif (contohnya kegagalan bagi seorang individu terkadang dianggap keberhasilan bagi individu yang lain), dan juga waktu (contohnya hari ini mungkin seseorang mengalami kesuksesan tetapi besok bisa jadi seseorang tersebut mengalami kegagalan) [18]. Oleh karena itu, dijelaskan 3 definisi dari keberhasilan:

(1) The success: sebuah inisiatif yang telah dicapai dan tidak pernah mengalami hasil yang tidak diinginkan secara signifikan.

(2) The partial success/failure: beberapa dari tujuan awal yang telah dicapai dan beberapa yang lain gagal.

(3) Total failure: sebuah inisiatif yang tidak pernah diimplementasikan atau sebuah sistem baru yang diimplementasikan namun benar-benar mengalami kegagalan secara cepat.

Dalam pandangan perspektif yang berbeda dari sukses dan gagal, tidaklah mudah untuk mendefinisikan sebuah kesuksesan dari aplikasi sistem informasi sebuah organisasi.

Penggunaan Sistem Informasi Kesehatan (SIK) dalam sektor kesehatan adalah untuk memfasilitasi transaksi dan distribusi dari proses pengolahan data khususnya rekap medis dari lokasi-lokasi yang berbeda [19]. Ada beberapa masalah yang belum bisa diselesaikan dan telah berkontribusi sebagai penghalang penggunaan SIK pada banyak negara-negara. Masalah utama 
adalah berhubungan dengan privacy system dan keamanan dari Sistim Informasi Kesehatan [20]

Penelitian terdahulu telah mengidentifikasi integrasi dari SIK dalam kontek-kontek yang berbeda dengan penerapannya. Tidak hanya menghubungkan antara pengguna internal dalam sebuah rumah sakit tetapi juga menghubungkan para stake holder dari wilayah yang berbeda dalam konteks dunia kesehatan [21]. Studi ini memperkenalkan ide-ide yang lebih maju untuk mengintegrasikan semua data kesehatan dan informsi-informasi lainnya antara negara-negara di ASEAN. Kondisi ini berhubungan dengan besarnya jumlah pasien-pasien di setiap negara termasuk diantaranya di Singapura, Malaysia dan Indonesia.

Sistim informasi kesehatan (SIK) atau e-heath adalah penggunaan dari teknologi komunikasi elektronik dan teknologi informasi untuk mencapai, mengirim, menyimpan dan mengecek ulang data kesehatan, informasi, dan pengetahuan klinis, pendidikan, dan tujuan-tujuan administrasi pada wilayah lokal atau lokasi yang terisolir. E-Health memiliki karakteristik unik yaitu baik pada tipe interaksi data dan pada perangkatnya [22]. Tipe-tipe dari e-health digunakan dalam penyimpanan, meneruskan dan menghubungkan dengan aliran proses informasi dan kegiatan-kegiatan penyimpanan. Tipe data memperlihatkan transfer data dalam teks, suara, foto atau kombinasinya. Penerapan dasar dari $e$-health dicatat dan dilaporkan pada data pasien, database, evaluasi dari kualitas pelayanan dan lain-lain. [22].

Catatan e-health yang sistematis menyediakan peluang yang besar bagi peningkatan kualitas dan keamanan dari healthcare, mengurangi biaya-biaya, meningkatkan hasil kesehatan yang berkelanjutan dari pasien-pasien, menyelamatkan hidup, waktu dan uang, membuat sistem kesehatan di Australia menjadi lebih efisien, dan menyediakan setiap individu di Australia dengan kemudahan dan keadilan akses pada healthcare.Secara teknologi, Australia memiliki dasar yang penting dalam penerapan sebuah sistem $e$-health nasional. Selain hal tersebut, Hampir semua GPs dan farmasi-farmasi di dukung oleh sistem komputer. Hampir semua rumah sakit - rumah sakit umum dalam tahapan-tahapan yang bervariasi dalam hal komputerisasi/ digital [23].

Sementara itu, di Indonesia penerapan e-health di Indonesia terbanyak adalah terkait dengan penggunaan m-health dan telemedicine. Penggunaan layanan kesehatan kepada masyarakat di Indonesia melalui telepon selular menggunakan voice, SMS (Short Message Service), dan akses data [22]. Dengan dua layanan tersebut, informasi layanan kesehatan dapat didistribusikan. Pengoptimalkan penggunaan TIK ini dapat diwujudkan melalui kerja sama dengan pemerintahan, yaitu antara Departemen Kesehatan dan Departemen Pendidikan sebagai penyedia sumber informasi kesehatan termasuk pemegang data rekam medis pasien, dan Departemen Komunikasi dan Informatika yang mengkoordinir infrastruktur telekomunikasi dan teknologi informasi yang akan digunakan. Disamping itu, Departemen Kependudukan dan Catatan Sipil juga dapat dilibatkan terutama dalam menggunaan fasilitas e-ktp untuk menyimpan data rekam medis terakhir bagi setiap penduduk di Indoensia.
Salah satu penelitian tentang penggunaan sistem infromasi kesehatan di Indonesia adalah di puskesmas di Kota Surabaya yaitu dilakukan oleh [21]. Hasil penelitian ini menggambarkan kurang optimalnya penggunaan teknologi informasi di puskesmas disebabkan oleh SDM-nya yang tidak siap, kurangnya komitmen pimpinan, perencanaan yang kurang matang dan kurang transparansi terkait layanan menggunakan IT. Untuk itu perlu peranan semua pihak untuk membantu mengoptimalkan penggunaan IT di beberapa layanan kesehatan oleh pemerintah maupun swasta.

Oleh karena itu perlu adanya studi lebih lanjut tentang pemanfaatan SIK di Sumatera Barat terutama melihat faktorfaktor yang mempengaruhi dalam menggunakan SIK di beberapa rumah sakit pemerintah di Kota Padang untuk dapat menyelidiki penerapan atau implementasi adopsi sistim informasi kesehatan (e-health) di rumah sakit pemerintah di Kota Padang.

\section{METODE}

Jenis penelitian ini adalah pengujian hipotesis atau Explanatory yang merupakan uji model tentang adopsi e-health, dengam tipe investigasi corelational study dan unit analisis adalah karyawan yang telah menggunakan sistem informasi/ aplikasi pada rumah sakit umum di Kota Padang, secara cross sectional. Dalam penelitian ini, teknik pemilihan sampel yang digunakan adalah teknik purposive sampling yaitu mengambil sampel berdasarkan kriteria yang pernah menggunakan sistim infromasi kesehatan di rumah sakit, sehingga terkumpul 80 orang sampel yang layak untuk mengisi kuisioner sebagai instrument dalam penelitian metode survey (Sekaran, 2012) pada tiga rumah sakit di Kota Padang.

Penelitian ini menggunakan pendekatan kuantitatif sehingga data yang terkumpul yang berupa jawaban kuisioner dalam bentuk angka-angka dianalsisi menggunakan metode Regresi Berganda dengan aplikasi STATA (Statistical software for Data Science). Hasil dari analisis ini akan digunakan untuk menjawab enam hipotesis dari penelitian ini. dan sebagian diperoleh melalui situs rumah sakit umum Kota Padang.

Teknik pengumpulan data yang digunakan yaitu metode kuisioner atau angket. Penelitian ini menggunakan skala likert 1 sampai 5 sebagai tingkat jawaban dari responden. Definisi operasional variabel di identifikasi dari objek dengan membedakan dari latar belakang pengalaman empiris, terdiri dari variabel indenpenden yaitu 6 faktor keasiapan (CR, SC, SC,GR, ER, PE) dan 1 faktor adopsi (AD) sebagai variabel dependen [32].

\section{HASIL DAN PEMBAHASAN}

Penelitian ini menginvestigasi adopsi penggunaan SIK/e-health dengan menggunakan beberapa faktor kesiapan dalam mengadopsi sistim informasi di rumah sakit [24]. Faktor yang diteliti terdiri dari faktor kesiapan $e$-health yaitu core readiness, structural readiness, societal readiness, engagement readiness and acceptance and use raediness. Core readiness merupakan realisasi evaluator terhadap persoalan pokok dalam penggunaan 
sistim informasi klinis dan pelayanan kesehatan kepada masyarakat. Structural readiness merupakan penilaian sumberdaya yang ada berupa sumberdaya manusia, organisasi dan teknologi. Societal readiness merupakan pemahaman tentang hubungan, komunikasi dan kolaborasi antar organisasi kesehatan terkait. Engagement readiness merupakan penilaian tentang paparan penyedian layanan kesehatan terhadap sistem $e$-health dan kemauan untuk berpartisipasi dalam dunia teknologi networking. Sementara, acceptance and use readiness adalah untuk menganalisis harapan upaya tenaga medis, harapan kinerja dan kesiapan oleh pemerintah atau administrasi selama mereka menggunakan sistem $e$-health [25].

\subsection{Pengembangan Hipotesis}

Berdasarkan kepada model adopsi $e$-health menggunakan factor kesiapan penggunaan sistim informasi, maka dikembangkan 6 hipotesis sebagai berikut:

H1: Adanya pengaruh yang signifikan antara Core Readiness (CR) terhadap adopsi e-health di rumah sakit pemerintah di Kota Padang.

H2: Adanya pengaruh yang signifikan antara Structural Readiness (SR) terhadap adopsi e-health di rumah sakit pemerintah di Kota Padang.

H3: Adanya pengaruh yang signifikan antara Societal Readiness (SC) terhadap adopsi e-health di rumah sakit pemerintah di Kota Padang

H4: Adanya pengaruh yang signifikan antara Engagement Readiness(GR) terhadap adopsi e-health di rumah sakit pemerintah di Kota Padang

H5: Adanya pengaruh yang signifikan antara Effort Readiness (ER) terhadap adopsi e-health di rumah sakit pemerintah di Kota Padang
H6: Adanya pengaruh yang signifikan antara Performance Expected $(P E)$ terhadap adopsi e-health di rumah sakit pemerintah di Kota Padang

\subsection{Profil Responden}

Hasil pengumpulan data telah di olah sehingga diperoleh data tentang profil responden dan hasil pengujian hipotesis. Berdasarkan dari data yang terkumpul, terdapat data personal responden yaitu dari identitas responden diklasifikasikan berdasarkan jenis kelamin, usia, lama bekerja dan pendidikan terakhir seperti pada Tabel 1 .

Berdasarkan data personal responden terlihat karakteristiknya yaitu mayoritas responden adalah perempuan $(77,5 \%)$, berumur antara 20-30 tahun (70\%), dengan masa kerja relatif sama antara 1- 7 tahun dan pendidikan terakhir dari Diploma dan sarjana (72, $5 \%)$.

\subsection{Uji Validitas dan Reliabilitas}

Pengujian validitas dari data yang terkumpul dilakukan dengan memperhatiakn nilai IR correlation yg lebih kecil dari $\mathrm{R}$ tabel yaitu 0.2199 harus dibuang. Pada tabel diatas nilai IR corr yang lebih kecil dari 0.2199 adalah 9 item indicator yaitu GR1, GR2, GR5, ER2, ER3, ER4, PE1, PE3, PE4, sehingga item-item pertanyaan tersebut harus dibuang dari model yang akan diteliti. Sementara untuk uji realibilitas dilakukan mempertimbangkan nilai Cronbach Alpha dari model yang diuji, dihasilkan nilai CR 0.918 , yang berarti angka tersebut lebih besar dari 0.6 sehingga data dianggap reliable.

Tabel 1. Responden Berdasarkan Data Personal

\begin{tabular}{|c|c|c|c|c|}
\hline No & Item & & Jumlah & Persentase (\%) \\
\hline \multirow[t]{2}{*}{1} & Jenis Kelamin & Lelaki & 18 & 22,5 \\
\hline & & Perempuan & 62 & 77,5 \\
\hline \multirow[t]{6}{*}{2} & Umur & $20-25$ & 25 & 31,25 \\
\hline & & $26-30$ & 31 & 38,75 \\
\hline & & $31-35$ & 9 & 11,25 \\
\hline & & $36-40$ & 10 & 12,25 \\
\hline & & $41-45$ & 4 & 5 \\
\hline & & 45 & 1 & 1,25 \\
\hline \multirow[t]{4}{*}{3} & Masa Kerja & $1-3$ & 23 & 28,75 \\
\hline & & $3-5$ & 20 & 25 \\
\hline & & $5-7$ & 16 & 20 \\
\hline & & 7 & 21 & 26,25 \\
\hline \multirow[t]{4}{*}{4} & Pendidikan & SMA & 15 & 18,75 \\
\hline & & Diploma & 26 & 32,5 \\
\hline & & Sarjana & 32 & 40 \\
\hline & & Pasca Sarjana & 7 & 8,75 \\
\hline
\end{tabular}

\subsection{Uji Asumsi Klasik}

\subsubsection{Uji Normalitas}

- Kolmogorov Smirnov; Nilai Kolmogorov Smirnov sebesar $0.876>$ dari 0.05 sehingga data terdistribusi normal.
Tabel 2. Nilai Kolmogorov Smirnov (K-S)

\begin{tabular}{llll}
\hline Smaller group & D & P-value & Correlated \\
\hline Res: & 0.0637 & 0.523 & \\
Cumulative: & -0.0414 & 0.760 & \\
Combined K-S: & 0.0637 & 0.902 & 0.876 \\
\hline
\end{tabular}


- Histogram dan PP Plot; untuk kedua hasil pengujian telah dihasilkan Grafik Histogram yang membentuk lonceng, sehingga data diartikan terdistribusi normal. Sementara untuk PP Plot telah dihasilkan grafik dengan titik data mendekati atau merapatkan ke garis miring sehingga data diartikan telah terdistribusi secara normal.

\subsubsection{Uji Heterokedasitisitas}

Uji heterokedastisitas; adalah menguji menggunakan :

- Breusch Pagan. Hasil dari tes ini adalah nilai probabilitas Breusch Pagan adalah 0.943. 0.05, sehingga analisis regresi terbebas dari gejala heterokedastisitas.
- $\quad$ Scatter Plot. Hasil pengujian mendapatkan grafik Scatter Plot secara acak dan tidak membentuk pola tertentu, sehingga data diartikan terbebas dari gejala heterokedasitas.

\subsubsection{Uji Multikolinearitas}

- $\quad$ VIF (Variance Inflation Factor); Terdapat semua nilai $\mathrm{VIF}<10$ dan nilai $1 / \mathrm{VIF}>0.1$ sehingga antara independent variabel tidak memiliki gejala multikolinearitas.

- Pearson Correlation; Tabel 3 memperlihatkan semua indikator memilki hubungannya yang kuat dengan variable asalnya.

Tabel 3. Pearson Correlation

\begin{tabular}{lllllll}
\multicolumn{1}{c}{ Variabel } & CR & SR & CR & GR & ER & PE \\
\hline CR & 1.0000 & & & & & \\
SR & -0.0404 & 1.0000 & & & & \\
SC & 0.1234 & 0.2792 & 1.0000 & & & \\
GR & 0.2584 & -0.0053 & 0.1324 & 1.0000 & & \\
ER & 0.0373 & -0.0561 & 0.2179 & -0.2027 & 1.0000 & \\
PE & 0.0374 & 0.0145 & 0.0808 & -0.2231 & 0.2312 & 1.0000 \\
\hline
\end{tabular}

\subsection{Analisis Regresi}

Tabel 4 memperlihatkan hasil uji Regresi untuk model adopsi ehealth di RS milik negara di Kota Padang.

Tabel 4. Hasil Analisis Regresi

\begin{tabular}{lclrlll}
\hline \multicolumn{1}{c}{ Adopsi } & Coef. & Std.Err. & $\mathbf{t}$ & P>t & 95\% Conf. Interval \\
\hline CR & .2869118 & .1114772 & 2.57 & 0.012 & .064738 & .5090856 \\
SR & .2059371 & .071574 & 2.88 & 0.005 & .0632902 & .345839 \\
SC & .2436128 & .1026606 & 2.37 & 0.020 & .0390105 & .4482151 \\
GR & .3696125 & .114038 & 3.24 & 0.002 & .1423351 & .59689 \\
ER & .3475446 & .1159335 & 3.00 & 0.004 & .1164894 & .5785998 \\
PE & .2350165 & .10853 & 2.17 & 0.034 & .0187165 & .4513165 \\
Cons & -3.10781 & .9145039 & -3.40 & 0.001 & -4.93041 & -1.285208 \\
\hline
\end{tabular}

\subsection{Uji Statistik}

- $\quad$ Hasil Uji T dapat dilihat pada Tabel 5. Tabel 5. Hasil uji T Statistik

\begin{tabular}{lll}
\hline Variabel & Nilai $\mathbf{p}>\mathbf{t}$ & Keterangan \\
\hline CR & 0.012 & Signifikan \\
SR & 0.005 & Signifikan \\
ScR & 0.020 & Signifikan \\
GR & 0.002 & Signifikan \\
ER & 0.004 & Signifikan \\
PE & 0.034 & Signifikan \\
\hline
\end{tabular}

- $\quad$ Uji F. Pengujian dilakukan dengan memperhatikan nilai Prob > F yang menunjukkan 0.000 yaitu lebih kecil dari 0.05 , sehingga variabel independen secara serentak mempengaruhi variabel dependen dengan rincian di bawah ini:
1. Number of obs $=80$

2. $\mathrm{F}(6,73)=10.76$

3. Prob $>\mathrm{F}=0.0000$

4. R-Squared $=0.4694$

5. Adj R-squared $=0.4258$

6. Root MSE $=.49554$

- $\quad$ Koefisien Determinasi (R2)

Nilai R-squared menunjukkan 0.425 artinya variabel independen mempempengaruhi variabel dependent sekitar $42 \%$, sementara sisa yang $58 \%$ dipengaruhi oleh variabel/faktor yang lain

\subsection{Pembahasan}

Penelitian ini menguji penggunaan sistim informasi kesehatan di tiga rumah sakit pemerintah di Kota Padang. Studi ini menguji 6 hipotesis dimana semua hipotesis memilki hubungan yang 
signifikan dengan penggunaan e-health di RS tersebut. Hipotesis yang di uji adalah hubungan faktor kesiapan dalam mengadopsi sistim informasi kesehatan (e-health) yang dibahas pada bagian berikut ini.

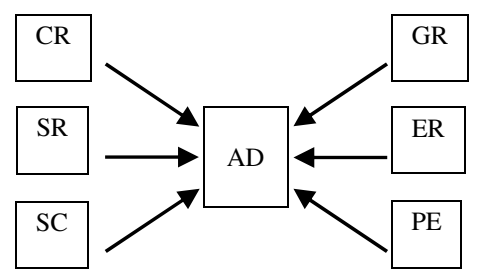

Gambar 1. Model Adopsi E-health

\subsubsection{H1; Pengaruh core readines (CR) terhadap adopsi e-health}

Hasil dari pengolahan data memperlihatkan faktor core readiness memiliki hubungan yang signifikan terhadapt adopsi e-health yang berarti hipotesis diterima. Hasil hipotesis ini menggambarkan bahwa penggunaan e-health di RS pemerintah di Kota Padang karena faktor kebutuhan kan sistim informasi itu sendiri, perbaikan atas ketidakpuasan dengan sistim manual, sudah punya pengalaman dalam menggunakan teknologi, serta untuk RS yang telah memiliki perencanaan untuk menggunakan sistim informasi.

\subsubsection{H2; Pengaruh Structural readines (SR) terhadap adopsi e-health}

Hasil pengujian hipotesis 2 memperlihatkan ketika RS mengadopsi e-health adalah RS yang sudah memiliki fasilitas teknologi hardware, software dan jaringan internet yang bagus termasuk ketersediaan dari pekerja dengan kemampuan dalam menggunakan teknologi/komputer.

\subsubsection{H3; Pengaruh Societal Readines (SC) terhadap adopsi e-health}

Pengujian hubungan societal readiness terhadap adopsi e-health yang signifikan, memperlihatkan bahwa jika mengadopsi ehealth perlu adanya kolaborasi dengan institusi lainnya yang terkait, untuk berbagai data serta informasi, untuk membentuk budaya sosial RS, termasuk memberikan pelayanan kepada mitra RS.

\subsubsection{H4; Pengaruh Engagement Readines (GR) terhadap adopsi e-health}

Hipotesis 4 memilki hasil pengujian yang signifikan antara engagement readines dengan e-health. Hasil pengujian ini memperlihatkan jika dalam megadopsi e-health perlu diperhatikan adanya manfaat dari penggunaan sistim ini, memilki keuangan RS yang mendukung, sikap yang siap untuk melakukan perubahan dan mampu melakukan pembelajaran yang berkelanjutan.

\subsubsection{H5; Pengaruh Effort Readines (ER) terhadap adopsi e-health}

Pengujian Hipotesis 5 adalah memiliki hubungan yang signifikan, sehingga diperlihatkan untuk megadopsi $e$-health perlu adanya pengetahuan dan pengalaman menggunakan teknologi, dan dukungan dari vendor selama menggunakan Sistim Infromasi Kesehatan (e-health).

\subsubsection{H6; Pengaruh Performance Expected (PE) terhadap adopsi e-health}

Hasil pengujian hipotesis 6 memperlihatkan hubungan yang signifikan dari faktor harapan yang diharapkan dengan adopsi $e$ health. Keadaan ini menggambarkan tentang penggunaan ehealth akan menghasilkan pelayanan yang bermutu, kepuasan dari pengguna (users) dan akan bermanfaat bagi RS dan pihak yang terkait.

\section{KESIMPULAN}

Penelitian ini bertujuan untuk menguji faktor-faktor kesiapan dalam menggunakan Sistim Informasi Kesehatan/SIK (e-health) di RS milik Negara/Pemerintah di Kota Padang. Faktor kesiapan yang uji adalah faktor Core Readiness (CR), Structural Readiness $(S R)$, Societal Readiness SC), Engagement Readiness (GR), Effort Readiness (ER), dan Performance Expected (PE). Hasil pengujian 6 hipotesis dihasilkan semua faktor tersebut memilki hubungan yang signifikan dalam mengadopsi e-health di RS. Sehingga dapat di sarankan kepada RS milik negara bahwa untuk menggunakan E-health mesti memperhatikan faktor kesiapan kegiatan pokok (core), kesiapan struktur teknologi (structural), kesiapan untuk berkolaborasi secara internal dan external (societal), kesiapan untuk mengoperasikan sistim (engagement), memiliki usaha untuk menggunakan sistim (effort) serta memilki harapan kinerja (Performance Expected) yang akan diperoleh ketika menggunakan $e$-health di RS masing-masing. Sehingga untuk penelitian berikutnya dapat dilakukan studi adopsi $e$-health di RS Umum atau Swasta dengan melibatkan semua pihak yang terkait dalam penggunaan sistim informasi kesehatan. Kemudan juga perlunya studi tentang komitmen pimpinan, dan ketersediaan dana dalam mengadopsi $e$-health di rumah sakit pemerintah di Indonesia. Penelitian terkait dengan good governance perlu dilakukan di RS selama menggunakan sistim informasi kesehatan.

\section{UCAPAN TERIMA KASIH}

Ucapan terima kasih diberikan Rektor Universitas Andalas yang telah mendanai penelitian ini melalui Hibah Percepatan Guru Besar tahun 2018 yaitu kontrak dengan LPPM Unand, dengan nomor 1646/XIV/R/KPT/2018. 


\section{DAFTAR PUSTAKA}

[1] R. H. Osborne, et. al, "The grounded psychometric development and initial validation of the health literacy questionnaire (HLQ)", BMC Public Health, 2013, Volume 13, No. 658, pages 1-17, DOI: doi.org/10.1186/1471-2458$\underline{13-658}$

[2] JuanHua $\mathrm{Li}$, et. al, “An e-health readiness assessment framework for public health services - Pandemic Perspective", in $45^{\text {th }}$ Hawaii International Conference on System Sciences, 2012, pp. 2800-2809.

[3] Leila Gholamhosseini, Haleh Ayatollahi, "The design and application of an e-health readiness assessment tool", Health Information Management Journal, Volume 46, Issue1, Pages 32-41, 2017, DOI: 10.1177/1833358316661065.

[4] Haryanto, "Kualitas Layanan, Fasilitas dan Harga Pengaruhnya Terhadap Kepuasan Pengguna Jasa Layanan Pada Kantor Samsat Manado", Jurnal "EMBA", Volume 1, Issue 3, Pages 750- 760, 2013.

[5] Internet Worldstats, "Penggunaan Internet terbanyak di Indonesia" akses online pada www.internetworldstats.com/asia.htm\#id, akses tanggal 02 Februari 2018.

[6] Bevaola Kusumasari, Widodo Agus Setianto, dan Li li Pang, "A Study on Digital Democracy Practice: Opportunities and Challenges of e-Health Implementation in Indonesia", Jurnal Ilmu Sosial dan Ilmu Politik, Volume 22, Issue 1, Pages 1-6, 2018, DOI: 10.22146/jsp.28863.

[7] Edy Kristianto, "E-health di Indonesia", Jurnal Teknik dan Ilmu Komputer, Volume 2, Issue 6, Pages 167-1771, 2013.

[8] J. Buhalis, 2011, E-Tourism, Contemporary Tourism Review, Goodfellow Publishers Limited, Woodeaton, Oxford, 2011

[9] B.Ramdani D. Chevers, D. A. Williams, "SMEs' adoption of enterprise applications A technology-organizationenvironment model", Journal of Small Business and Enterprises Development, 2013, Volume 20, Nomor 4, pp 735-753.

[10] E. Daniel, D. J. Grimshaw, “An exploratory comparison of electronic commerce adoption in large and small enterprises", Journal of Information, 2002, Volume. 17, Nomor. 3, pp 133-147.

[11] Salwani, I. Mohamed, G. Marthandan, Norzaidi, Mohd. Daud., and Chong, S. Choy. (2008). E-commerce usage and business performance in the Malaysian tourism sector: empirical analysis. Journal of Information Management \& Computer Security. 2008, Volume 17, Nomor 2, pp. 166-185

[12] V.Serafeimidis, "Information systems investment evaluation: conceptual and operational explorations", unpublished $\mathrm{PhD}$ thesis, London School of Economics and Political Science, 1998.

[13] M.G. Martinsons \& Chong, P.K.C, 1999, 'The influence of human factors and specialist involvement on information systems', Human Relations, 1999, Volume. 52, Nomor 1, pp. 123-152.

[14] G. Whyte \& A. Bytheway, "Factors affecting information systems success", International Journal of Service Industry Management, 1996, Volume 7, nomor 1, pp. 74-93.
[15] D.H. Drury \& A.F. Farhoomand, "A hierarchical structural model of information system success", INFOR, 1998, Volume 36, nomor 1/2. pp. 25-40.

[16] Myers, Kapppelman \& Prybutok 1998 Myers, B.L, Kappelman, L.A., \& Prybutok, V.R, 1998, ‘A comprehensive model for assessing the quality and productivity of the information systems function: toward a theory for information systems assessment', Information Resources management Journal, 1998, Volume10, nomor 1, pp. 6-25.

[17] Garrity \& G.L. Sanders, 1998, "Introduction to Information Systems Success Measurement," in Information Systems Success Measurement, Idea Group Publishing, pp. 1-12.

[18] R. Heeks 2002, "Information systems and developing countries: failure, success and local improvisations", The Information Society, 2002, Volume 18, pp.101-112.

[19] M.Vittaca, M.Mazzu, S. Scalvini, "Socio-technical and organizational challenges to wider e-health implementation", Chronic Respiratory Disease, 2009, Volume. 6, Nomor 2, pp. 91-97.

[20] W. Lankton, "Healthcare information systems research, revelations and visions", European Journal of Information Systems, 2007. Volume 16, Nomor 6, pp. 669-671.

[21] I. Widiyastuti, "Analisa aplikasi e-health berbasis websitedi instansi Kesehatan Pemerintah dan Swasta serta potensi implementasi di Indonesia", Jurnal Penelitian Ilmu Pengetahuan dan Teknologi Komunikasi, Volumen 10, Nomor2, Desember 2008.

[22] S. Soegijoko, "Perkembangan terkini telemedika dan ehealth serta prospek aplikasi di Indonesia", Seminar Nasional Aplikasi Teknologi dan Informasi (SNATI), 19 Juni 2010, pp 1-8.

[23] E. Coiera, M. Kidd, M. Haikerwal, A call for national ehealth clinical safety governance, Medical Journal of Australia, 2012, Volume. 196, Nomor. 7, pp. 430-431.

[24] Khoja, et al., 2007, Conceptual Framework for Development of Comprehensive e-Health Evaluation Tool, Telemedicine and e-Health, pp. 48-52.

[25] Billy M. Kalema \& Mmamolefe R. Kgasi, “Leveraging eheath for future-oriented healthcare systems in Developing countries", IJISDC 2014, Volumen65, Nomor 8, pp 1-11.

\section{BIODATA PENULIS}

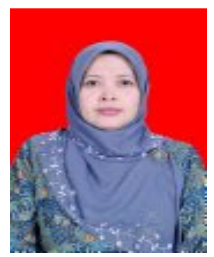

\section{Vera Pujani}

Penulis adalah staf pengajar di Fakultas Ekonomi Universitas Andalas. Riset yang pernah dilakukan terkait dengan EBusiness, E-commerce, Small Business, Website. 


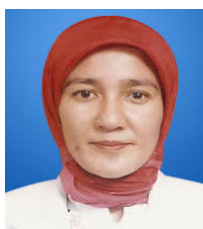

\section{Rima Semiarty}

Penulis adalah staf pengajar di Fakultas Kedokteran Universitas Andalas. Riset yang pernah dilakukan terkait dengan Pelayanan Kesehatan Masyarakat, Kepemimpin Stratejik, Kualitas Pelayanan.

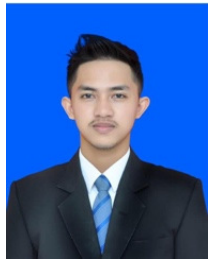

\section{Dede Wahyu Tri Kotama}

Penulis adalah Alumni di Fakultas Ekonomi Universitas Andalas. Sebagai mahasiswa bimbinngan dari penulis pertama 